| Original | Article |

\title{
Off-pump versus on-pump coronary artery bypass grafting in patient of impaired renal function
}

\author{
Md. Alauddin, Aslam Hossain, Rezwanul Hoque and Asit Baran Adhikary
}

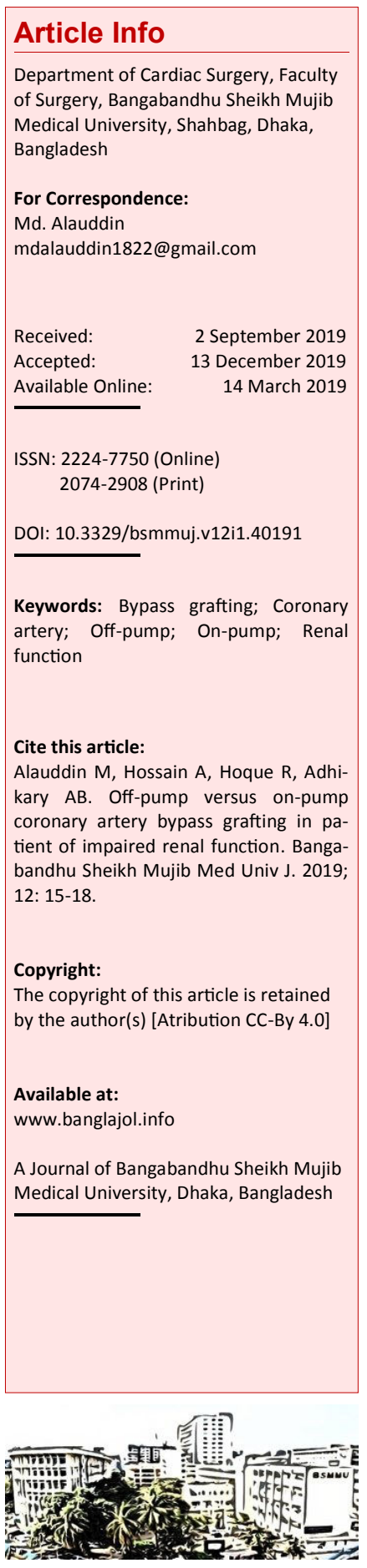

\section{Abstract}

The purpose of this study was to compare the renal function in patients undergoing coronary artery bypass grafting in off-pump and on-pump having pre-operative impaired renal function. In the on-pump, the serum creatinine and urea levels were significantly increased on post-operative day 1, 3 and 7 . On day 1, it was maximum, then gradually decreased but not reached to preoperative level. In case of off-pump, serum creatinine and urea levels were significantly increased on post-operative day 1 and 3. On day 1, it was maximum. Then decreased and the serum creatinine reached below pre-operative level on day 7. In case of on-pump, the creatinine clearance rate was significantly decreased on post-operative day 1, 3 and 7 . On day 1 , it was minimum. Then gradually increased but not reached the pre-operative level. In case off-pump, the creatinine clearance rate was significantly decreased on day 1 and 3. On day 1, it was minimum, then gradually increased and reached above the pre-operative level. A significant low level creatinine clearance rate was observed in on-pump group. Renal function was better preserved in patients undergoing off-pump in comparison to on-pump coronary artery bypass grafting.

\section{Introduction}

Coronary artery bypass grafting is a common surgical procedure in cardiac surgery. Conventional bypass grafting using cardiopulmonary bypass has been considered as the gold standard for treatment of ischemic heart disease. 1 However, the evidence increasing that cardiopulmonary bypass may be responsible for some of the morbidity. To avoid the detritus effects of cardiopulmonary bypass, increasing interest in off-pump coronary artery bypass as a safe alternative to conventional coronary revascuralization. 1,2 The risk factors for cardiac disease like hypertension, diabetes or metabolic syndrome are also the risk factors for chronic kidney disease. 2 The patient with renal dysfunction requiring coronary artery bypass graft surgery represents a complex group of patients with an accelerated process of atherosclerosis have more risk to develop renal failure..$\underline{3,4}$

Post-operative renal dysfunction is a serious complication of cardiac surgery. .5 It is associated with increase morbidity, mortality and ICU stay, particularly if require hemodialysis. $\frac{6,7}{\underline{7}}$ despite advances in cardiopulmonary bypass technology, anesthesia, per-operative hemodynamic monitoring and antibiotic therapy. $\frac{8,9}{9}$ The objective of this study was to see the renal impairment in off-pump and on-pump in patient having pre-operative impaired renal function.

\section{Materials and Methods}

\section{Patients}

This observational study was done on 50 onpump (mean age: $57.6 \pm 4.8$ years) and 50 offpump (mean age: $59.3 \pm 4.1$ years) who underwent elective bypass grafting. The patients were randomly selected to on-pump and offpump group with serum creatinine levels $>1.5$ $\mathrm{mg} / \mathrm{dL}$ and $<5 \mathrm{~g} / \mathrm{dL}$.

\section{Anesthetic technique}

Induction was done with pentothal sodium, midazolam and fentanyl. The maintenance was done with isoflurane and fentanyl. Muscle relaxation ensured with pancuronium. $\frac{5,10}{10}$

Surgical aspect on-pump technique: Median sternotomy was done. The saphenous vein and left internal mammary artery were harvested. Cardiopulmonary bypass was established with ascending aortic cannulation and a two stage venous cannulation in right atrium. The circuit was primed with 1,000 mL Hartmann`s solution, $0.5 \mathrm{~g} / \mathrm{kg}$ of mannitol, $7 \mathrm{~mL} \mathrm{10 \%} \mathrm{calcium}$ gluconate and $60 \mathrm{mg}$ heparin. The pump flow was non-pulsatile, flow rate was $2.4 \mathrm{~L} / \mathrm{m}^{2} / \mathrm{min}$, mean arterial pressure was $60-80 \mathrm{~mm}$ of $\mathrm{Hg}$ was maintained. The systemic temperature was kept between 34 to $36^{\circ} \mathrm{C}$. The heart was arrested by using warm blood cardioplegia.11 After completion of distal anastomosis, aortic cross clamp 


\begin{tabular}{|c|c|c|c|c|}
\hline \multicolumn{5}{|c|}{ Table I } \\
\hline \multicolumn{5}{|c|}{ Comparison of renal parameters in on-pump and off-pump group } \\
\hline \multicolumn{2}{|l|}{ Renal parameter } & On-pump & Off-pump & $\mathrm{p}$ value \\
\hline \multirow{5}{*}{$\begin{array}{l}\text { Serum creatinine } \\
(\mathrm{mg} / \mathrm{dL})\end{array}$} & Pre-operative & $1.9 \pm 0.3$ & $1.9 \pm 0.3$ & 1.000 \\
\hline & Post-operative day 1 & $2.5 \pm 0.4$ & $2.1 \pm 0.3$ & $<0.001$ \\
\hline & Post-operative day 3 & $2.3 \pm 0.3$ & $1.9 \pm 0.3$ & $<0.001$ \\
\hline & Post-operative day 7 & $2.2 \pm 0.4$ & $1.7 \pm 0.3$ & $<0.001$ \\
\hline & $\mathrm{p}$-value & $<0.001$ & $<0.001$ & \\
\hline \multirow[t]{5}{*}{ Blood urea $(\mathrm{mg} / \mathrm{dL})$} & Pre-operative & $45.1 \pm 4.2$ & $43.1 \pm 6.9$ & 0.083 \\
\hline & Post-operative day 1 & $61.5 \pm 5.6$ & $58.0 \pm 5.7$ & 0.003 \\
\hline & Post-operative day 3 & $57.9 \pm 5.5$ & $54.4 \pm 5.0$ & 0.001 \\
\hline & Post-operative day 7 & $52.5 \pm 6.9$ & $48.0 \pm 6.1$ & 0.001 \\
\hline & p-value & $<0.001$ & $<0.001$ & \\
\hline \multirow{5}{*}{$\begin{array}{l}\text { Creatinine clearance } \\
(\mathrm{mL} / \mathrm{min})\end{array}$} & Pre-operative & $59.5 \pm 15.8$ & $54.2 \pm 16.0$ & 0.098 \\
\hline & Post-operative day 1 & $34.7 \pm 11.0$ & $46.6 \pm 15.4$ & $<0.001$ \\
\hline & Post-operative day 3 & $41.2 \pm 15.0$ & $53.8 \pm 15.3$ & $<0.001$ \\
\hline & Post-operative day 7 & $45.2 \pm 17.1$ & $60.5 \pm 14.5$ & $<0.001$ \\
\hline & $p$-value & $<0.001$ & $<0.001$ & \\
\hline
\end{tabular}

Data are expressed as mean $\pm \mathrm{SD}$; $\mathrm{p}$ value reached from unpaired Student's t-test between group and ANOVA for within group

was removed and the proximal anastomosis completed with partial clamping of the aorta. Heparin was given at a dose of $300 \mathrm{IU} / \mathrm{kg}$ and activated clotting time of $480 \mathrm{sec}$ or above was maintained before commencement of cardio-pulmonary bypass. 12 The activated clotting time was monitored at $30 \mathrm{~min}$ interval and additional 3,000 IU of heparin was administered if needed.

\section{Surgical aspect off-pump technique}

The sternotomy was done. The saphenous vein and left internal mammary artery were harvested. The heart exposed and stabilized for the anastomosis was a combination of technique. 13 The target artery was identified, exposed and snared with 4-0 prolene above the point for anastomosis. The coronary artery was then opened, intracoronary shunt introduced and anastomosis performed. At that time, the mean arterial pressure above $70 \mathrm{~mm}$ of $\mathrm{Hg}$ was maintained using inotropes. $9100 \mathrm{IU} / \mathrm{kg}$ of heparin was used before anastomosis. The activated clotting time was 250 to $350 \mathrm{sec}$ was maintained. Protamine used to reverse the effect of heparin.

\section{Sample collection}

The blood samples were collected for the estimation of creatinine and urea at pre-operatively, postoperative day 1,3 and 7 . The urine output was maintained more than $0.5 \mathrm{~mL} / \mathrm{kg} /$ hour in postoperative period if needed diuretics were used.

\section{Laboratory methods}

The serum creatinine and urea levels were mea- sured using commercial reagent kits. The creatinine clearance was calculated using the standard formula: $\underline{14}$

Creatinine clearance $(\mathrm{mL} / \mathrm{min})=(140$-age $) \times$ weight in $\mathrm{kg} \times 0.85 / 72 \times$ serum creatinine in $\mathrm{mg} / \mathrm{dL}$

For female patient, the result was multiplied by 0.85 .

\section{Statistic analysis}

Statistical analysis was done by unpaired 't'-test, one-way ANOVA test and Chi-square test.

\section{Results}

Table I shows the comparison of renal parameters in on- and off-pump groups in pre-operative and post -operative days (day 1, 3 and 7). Serum creatinine level in case of on-pump group during preoperative period was $1.9 \pm 0.3 \mathrm{mg} / \mathrm{dL}$ which was $2.5 \pm 0.4 \mathrm{mg} / \mathrm{dL}$ on post-operative day. One-way ANOVA test showed significant difference among the serum creatinine levels. Similarly serum urea level was increased from $45.1 \pm 4.2 \mathrm{mg} / \mathrm{dL}$ to $61.5 \pm$ $5.6 \mathrm{mg} / \mathrm{dL}$ One-way ANOVA test showed significant differences.

In case of off-pump group in pre-operative serum creatinine level was $1.9 \pm 0.3 \mathrm{mg} / \mathrm{dL}$ which was 1.7 $\pm 0.3 \mathrm{mg} / \mathrm{dL}$ on day 7 of post-operative group. Oneway ANOVA test significant difference. Serum urea in pre-operative group was $43.1 \pm 6.9 \mathrm{mg} / \mathrm{dL}$ which was $48.0 \pm 6.1 \mathrm{mg} / \mathrm{dL}$ on day 7 of post-operative group. One-way ANOVA test showed significant difference.

\section{Discussion}

In on-pump group serum creatinine and serum urea were significantly increased in first, third and seventh post-operative day. In first day it was maximum then gradually decreased but not reached the pre-operative level. In off-pump group serum creatinine and serum urea were significantly increased in first and third day. In first day it was maximum then gradually decreased and serum creatinine reached below the pre-operative level but serum urea not reached the pre-operative level. This parameters were increased significantly first and third day after bypass grafting in both the groups which are in agreement with the findings of the studies conducted by Pramodh et al. 5 Serum urea, and creatinine levels were significantly higher in on -pump group in comparison to off-pump group and a decrease serum creatinine below pre-operative level indicate improvement of renal function in offpump group. $\underline{15,16}$

In on-pump group, creatinine clearance rate was significantly decreased in the first, third and 
seventh post-operative day. In the first day, it was maxi-mum then gradually increased but not reached the pre-operative level. In off-pump group creatinine clearance rate was significantly decreased in first and third day. In the first day, it was maximum then gradually increased and reached above the pre-operative level. A significant low level of creatinine clearance rate was observed in on -pump group. This finding is in consistent with the finding of the study conducted by Pramodh et al.5 and Lin and Hwang 17 It indicates that on-pump technique is more prone to develop renal dysfunction after bypass grafting.

In a prospective randomized trial of 50 patients, Ascione et al. (1999) 8 demonstrated a slightly greater decrease in 24 hours post-operative creatinine clearance in on-pump compared with offpump and no significant difference between pre and post-operative renal function in this study group which is not consistent with the findings of our study.

There was a significant difference among the preoperative, first, third and seventh post-operative day which may be due to poor renal perfusion due to hypotension. Many per-operative conditions may lead to an oxygen supply and demand imbalance at the renal level such as low cardiac output state, renal vasoconstriction, hemodilution, hypotension, and loss of pulsatile flow during cardiopulmonary bypass.18 Therefore, this pathophysiological condition should be considered as one of the possible explanation for renal damage in cardiac surgery. Similar findings were evident in other studies.19 Here, our findings are partially consistent with the previous findings of Ooi et al. (2008) 19 where renal function deteriorated significantly in first 4 days in on-pump group. The changes were not seen in the off-pump group. It should be noted that many studies revealed the effects of off-pump group such as hypotension, low cardiac output and dysrhythmia. 20

\section{Conclusion}

Renal function is comparatively better preserved in early post-operative days in off-pump technique than on-pump technique.

\section{References}

1. Yacoub M. Off-pump coronary bypass surgery: In search of an identity. Circulation 2001; 104: 1743-45.

2. Sarnak MJ. Cardiovascular complications in chronic kidney disease. Am J Kidney Dis. 2003; 41: 11-17.

3. Liu JY, Birkmeyer NJ, Sanders JH, Morton JR, Henriques HF, Lahey SJ, Dow RW, Maloney C,
DiScipio AW, Clough R, Leavitt BJ. Risks of morbidity and mortality in dialysis patients undergoing coronary artery bypass surgery. Circulation 2000; 102: 2973-77.

4. Chawla LS, Zhao Y, Lough FC, Schroeder E, Seneff MG, Brennan JM. Off-pump versus on-pump coronary artery bypass grafting outcome stratified by pre-operative renal function. J Am Soc Nephrol. 2012; 23: 1389-97.

5. Pramodh K, Vani, Muralidhar K. Renal function following CABG: On-pump vs off-pump. Indian J Thorac Cardiovasc Surg. 2003; 19: 169-73.

6. Tang ATM, Thomas R, Knott J, Nanson J, Ohri SK, Smith D. Beating heart coronary surgery and renal function: A prospective randomized study. Crit Care. 2001; 5: 3-5.

7. Mangos GJ, Brown MA, Chan WYL, Horton D, Trew P, Whitworth JA. Acute renal failure following cardiac surgery: Incidence, outcome and risk. Aust N Z J Med. 1995; 25: 284-89.

8. Ascione R, Lleoyd CT, Underwood MJ, Gomes WJ, Angelini GD. On-pump versus off-pump coronary revascularization of renal function. Ann Thorac Surg. 1999; 68: 493-98.

9. Akhter S, Khan S, Mehdi T, Nasiruddin M, Mollah $\mathrm{FH}$. Renal function before and after coronary artery bypass grafting (CABG): Off-pump vs. onPump. Bangladesh J Med Biochem. 2013; 3: 36-41.

10. Traynor J, Mactier R, Geddes CC, Fox JG. How to measure renal function in clinical practice. BMJ. 2006; 333: 733-37.

11. Calafiore AM, Teodori G, Mezzetti A, Bosco G, Verna AM, Di Giammarco G, Lapenna D Intermittent antegrade warm blood cardioplegia. Ann Thorac Surg. 1995; 59: 398-402.

12. Badruzzaman M, Hossain A, Adhikary AB, Quader SA, Kamal S, Saha SK. Evaluation of myocardial protection in off-pump vs on-pump coronary bypass surgery by troponin I estimation. Bangladesh Med Res Counc Bull. 2010; 36: 93-96.

13. Lucchetti V, Angelini GD. An inexpensive method of heart stabilization during coronary artery operations without cardiopulmonary bypass. Ann Thorac Surg. 1998; 65: 1477-78.

14. Cockcroft DW, Gault MH. Prediction of creatinine clearance from serum creatinine. Nephron 1976; 16; 31-41.

15. Chamberlain MH, Ascione R, Reeves BC, Angelini GD. Evaluation of the effectiveness of off-pump coronary artery bypass grafting in high risk patients: An observational study. Ann Thorac Surg. 2002; 73: 1866-73.

16. Bull DA, Neumayer LA, Stringham JC, Meldrum P, Affleck DG, Karwande SV. Coronary artery bypass grafting with cardiopulmonary bypass versus offpump cardiopulmonary bypass grafting: Does eliminating the pump reduce morbidity and cost? 
Ann Thorac Surg. 2001; 71: 170-75.

17. Lin WF, Hwang DF. Application of species-specific PCR for the identification of dried bonito product (Katsuobushi). Food Chem. 2008; 106: 390-96.

18. Haines N, Wang S, Under A, Alkan T, Akcevin A A clinical outcomes of pulsatile and non-pulsatile mode of perfusion. J Extra Corpor Technol. 2009; 41: p 26-29.
19. Ooi JSM, Rahman MRA, Shah SA, Dimon MZ. Renal outcome following on and off-pump coronary artery bypass surgery. Asian Cardiovasc Thorac Ann. 2008; 16: 468-72.

20. Ahmed NU, Hasan K, Raha SK. Early outcome of Off-pump coronary artery bypass graft surgery in patients with multivessel coronary artery disease. Bangladesh Med J. 2014; 41: 8-14. 